\title{
PENGEMBANGAN MULTIMEDIA PEMBELAJARAN PADA STANDAR KOMPETENSI MEMPERBARUI HALAMAN WEB DI SMK
}

\author{
Hendri Ari Kus Indriastoro \\ SMK N 1 Pengasih \\ hakiyogya@gmail.com \\ Zainur Rofiq \\ Universitas Negeri Yogyakarta \\ zainur_rofiq@yahoo.co.id
}

\begin{abstract}
Abstrak
Penelitian ini bertujuan untuk: (1) menghasilkan produk multimedia pembelajaran standar kompetensi Memperbarui Halaman Web yang layak dan sesuai kebutuhan siswa, (2) mengetahui efektivitas multimedia pembelajaran. Penelitian ini menggunakan model penelitian dan pengembangan dengan tiga tahapan yaitu perencanaan, desain dan pengembangan. Setelah produk awal selesai, dilakukan evaluasi formatif (validasi kelayakan produk oleh ahli materi dan ahli media), Beta Test I dan Beta Test II. Pada tahap akhir dilakukan evaluasi sumatif. Selanjutnya data dianalisis menggunakan analisis deskriptif. Hasil penelitian menunjukkan bahwa: (1) kelayakan produk pada komponen lingkup pembelajaran diperoleh skor sebesar 4,51, pertimbangan afektif diperoleh skor sebesar 4,73, informasi pelengkap sebesar 4,66, antarmuka sebesar 4,46, navigasi sebesar 4.68, pedagogi sebesar 4.64, dan ketahanan produk sebesar 4.47. (2) hasil belajar siswa pada saat pretest diperoleh rerata sebesar 6,34 sedangkan hasil belajar siswa pada posttest diperoleh rerata sebesar 8,47. Berdasarkan hasil tersebut diperoleh $N$-Gain sebesar 0,71 (tergolong klasifikasi tinggi). Berdasarkan N-Gain yang tinggi maka produk Multimedia Pembelajaran efektif untuk meningkatkan skor test hasil belajar.
\end{abstract}

Kata Kunci: multimedia pembelajaran, memperbarui halaman web

\section{DEVELOPING LEARNING MULTIMEDIA STANDAR COMPETENCY UPDATING WEB PAGE IN SMK}

\begin{abstract}
This research aims to (1) obtain feasible learning materials which meet satisfy the learning need of the ten-year students majoring multimedia and (2) find out the effectiveness of their learning process in the standar competency Updating Web Pages as reflected by their achievement test score increase. Comprising three main stages: planning, designing, and developing, it includes formatif evaluation as the initial result emerges. Alpha Test is carried out to validate its media content feasibility, Beta Test I and Beta Test II. By the end of stages summative evaluation. Data are processed in descriptive analysis. Research results in (1) the very high level offeasibilty in content coverage component (scored 4,51), affective consideation (4,73), information Adequace (4,66), interface (4,46), navigation (4,68), pedagogical (4,64), and robustness (4,47); (2) the high level of students' achievements progress students average score is 6,34 in pretest as compared to 8,47 in posttest, which mean 0,71 N-Gain. The high level of $N$-Gain leads to a conclusion that the multimedia learning material for the standar competency Updating Web Pages is effective to increase achievement score.
\end{abstract}

Keyword: multimedia learning, updating web pages. 


\section{PENDAHULUAN}

Perkembangan teknologi informasi dan komunikasi yang sangat pesat mendorong lembaga pemerintah, dunia usaha, dan dunia pendidikan berlomba-lomba memanfaatkan teknologi internet untuk meningkatkan efisiensi dan efektivitas pelayanan. Salah satu langkah yang dilakukan dengan membuat suatu portal website. Website memberi kemudahan dalam komunikasi, penyajian informasi, dan transaksi yang cepat menggunakan internet. Komunikasi dalam sistem administrasi berlangsung dalam hitungan jam, bukan hari atau minggu. Informasi dapat dicari dari kantor, rumah, bahkan mobile di manapun tanpa harus hadir secara langsung.

Keberadaan website memiliki peranan yang penting dan telah menjadi fasilitas utama bagi dunia pendidikan. Melalui website, siswa dapat mengakses informasi-informasi yang tidak hanya berupa teks tetapi bisa juga berupa gambar, suara, video dan animasi. Guru dan siswa dengan mudah mendapatkan berbagai informasi yang dibutuhkan, baik melalui artikel-artikel ataupun modul-modul yang telah disediakan dalam website. Website memfasilitasi guru dan siswa belajar secara menantang, mandiri, bervariasi, dan menyenangkan. Website juga merupakan salah satu media penyampaian informasi dan publikasi yang mudah diakses dari mana saja, kapan saja tanpa terbatas ruang dan waktu.

Berdasarkan Kurikulum KTSP tahun 2012 SMK Negeri 1 Pengasih, tujuan Kompetensi Keahlian Multimedia salah satunya adalah menjadi pengembang web dengan membekali siswa dengan keterampilan, pengetahuan dan sikap agar kompeten dalam mengembangkan laman (website) interaktif. Salah satu standar kompetensi yang berhubungan dengan tujuan kompetensi keahlian Multimedia tersebut di atas adalah Memperbarui Halaman Web.

Berdasarkan hasil analisis kebutuhan siswa di lapangan menunjukkan bahwa siswa masih menganggap materi pembelajaran Memperbarui Halaman Web merupakan materi yang sulit karena siswa harus memahami dan menguasai banyaknya sintak/tag HTML dalam bahasa pemrograman web. Pembelajaran yang diterapkan saat ini masih sebatas menggunak- an metode klasikal yaitu ceramah dan demonstrasi dengan sumber belajar berupa modul dan buku teks, akibatnya motivasi belajar dan tingkat pemahaman siswa terhadap materi pembelajaran masih rendah. Selain itu, pembelajaran dengan metode dan media seperti tersebut tidak memberi kesempatan yang luas bagi siswa untuk belajar secara mandiri. Siswa juga belum pernah diperkenalkan materi pembelajaran Memperbarui Halaman Web dalam bentuk produk multimedia pembelajaran yang mampu mensimulasikan langkah-langkah pembuatan halaman web. Selanjutnya siswa berharap materi pembelajaran Memperbarui Halaman Web dapat disajikan dengan sumber belajar yang lebih bervariasi.

Hasil wawancara analisis kebutuhan pada Standar Kompetensi Memperbarui Halaman Web yang dilakukan dengan Ketua Program Keahlian Multimedia dan beberapa Guru Multimedia di SMK Negeri 1 Pengasih menunjukkan bahwa hasil belajar siswa pada standar kompetensi Memperbarui Halaman Web belum sesuai yang diharapkan dan masih perlu ditingkatkan lagi karena hasil yang dicapai siswa belum seluruhnya memenuhi kreteria ketuntasan minimal (KKM) serta masih ada beberapa siswa yang harus mengikuti program remidi/perbaikan.

Permasalahan lain yang dijumpai dalam kegiatan pembelajaran adalah siswa mengalami kesulitan dalam memahami dan menguasai banyaknya sintak/tag HTML dalam bahasa pemrograman web. Media pembelajaran yang digunakan berupa modul cenderung membosankan, kurang interaktif dan komunikatif dalam mentransfer pengetahuan akibatnya pemahaman siswa masih rendah. Media pembelajaran dalam bentuk video yang ditampilkan melalui LCD Proyektor masih terbatas demonstrasi langkah-langkah membuat halaman web, dan belum dapat merangsang siswa untuk belajar mandiri.

Media dan sumber belajar merupakan salah satu sarana yang menunjang keberhasilan pendidikan. Ketersediaan sumber belajar, seperti buku teks, modul, tutorial, atau internet akan berpengaruh terhadap pengetahuan yang diperoleh siswa. Semakin banyak dan variasi sumber belajar yang dapat diperoleh siswa me- 
mungkinkan lebih banyak informasi yang diperoleh siswa.

Media dapat menyampaikan informasi yang dapat didengar (audio) dan dapat dilihat (visual), sehingga dapat mendeskripsikan suatu masalah, suatu konsep, suatu proses atau prosedur yang bersifat abstrak dan tidak lengkap menjadi lebih jelas dan lengkap. Media dapat membantu guru dan siswa melakukan komunikasi dua arah secara aktif.

Multimedia interaktif adalah suatu multimedia yang dilengkapi dengan alat pengontrol yang dapat dioperasikan oleh pengguna sehingga pengguna dapat memilih apa yang dikehendaki untuk proses selanjutnya, bertanya, dan mendapatkan jawaban yang mempengaruhi komputer untuk mengerjakan fungsi selanjutnya (Sutopo, 2003, p7).

Selanjutnya (Alessi \& Trollip, 2001, p.10) mengkategorisasikan multimedia interaktif menjadi delapan metodologi, yaitu: (1) tutorial, (2) hypermedia, (3) drill, (4) simulasi, (5) games, (6) perkakas dan lingkungan belajar open-ended, (7) tes, dan (8) belajar berbasis web.

Model pembelajaran simulasi adalah situasi buatan (artifical) yang menyerupai kondisi dan situasi yang sesungguhnya atau melakukan latihan nyata tanpa harus menghadapi reksiko yang sebenarnya. Simulasi dilengkapi dengan petunjuk penggunaannya berupa bahan penyerta (learning guides). Interaksi dalam bentuk simulasi berupa pemberian umpan balik untuk memberi informasi tentang tingkat pencapaian hasil belajar siswa setelah mengikuti program simulasi. Simulasi bertujuan memberi kesempatan kepada siswa untuk melakukan praktik dan latihan (Munir, 2012, p.62).

Pengembangan multimedia pembelajaran mampu mengatasi permasalahan keterbatasan infrastruktur dan meningkatkan hasil belajar siswa. Sebagaimana yang diungkapkan oleh Munir bahwa penggunaan multimedia pembelajaran dapat menarik perhatian siswa sehingga membangkitkan minat dan motivasi belajar, dapat memberikan penjelasan yang lebih baik dan lengkap terhadap sesuatu permasalahan, memudahkan untuk mengulang materi pelajaran, memungkinkan adanya persamaan pendapat dan persepsi yang benar terhadap suatu materi pembelajaran, membantu siswa belajar secara individu, kelompok dan klasikal, materi pembelajaran lebih lama diingat dan mudah untuk diungkapkan kembali dengan cepat dan tepat, mempermudah dan mempercepat guru menyajikan materi pembelajaran dalam proses pembelajaran, serta mengatasi keterbatasan ruang, waktu dan indera (Munir, 2012:150-151).

Berdasarkan paparan tersebut, maka pengembangan multimedia pembelajaran mampu memberikan solusi permasalahan pembelajaran pada standar kompetensi Memperbarui Halaman Web.

\section{METODE PENELITIAN}

\section{Model Pengembangan}

Metodologi penelitian yang digunakan adalah metode Research and Development (penelitian dan pengembangan). Model pengembangan yang digunakan untuk mengembangkan multimedia pembelajaran adalah model yang dikembangkan oleh (Alessi \& Trollip, 2001, p.408-p.413).

\section{Waktu dan Tempat Penelitian}

Penelitian ini dilaksanakan bulan Mei sampai dengan Juni 2013. Penelitian ini dilakukan di SMK N 1 Pengasih.

\section{Subjek Penelitian}

Subjek uji coba dalam pengembangan produk multimedia pembelajaran ini yakni satu orang ahli materi dan satu orang ahli media pada tahapan validasi data. Pada tahapan uji coba produk yang menjadi subyek uji coba adalah siswa kompetensi keahlian Multimedia SMK Negeri 1 Pengasih semester genap. Pada tahap uji coba jumlah subjek terdiri dari 31 siswa, dengan rincian 6 siswa untuk uji coba Beta Test I dan 26 orang untuk uji coba Beta Test II.

Subjek uji coba pada tahap evaluasi sumatif adalah adalah siswa kelas X Kompetensi Keahlian Multimedia yang berjumlah 31 siswa. Pemilihan jenjang kelas $\mathrm{X}$ sebagai subyek penelitian adalah karena standar kompetensi Memperbarui Halaman Web diberikan pada jenjang tersebut. 


\section{Jenis Data}

Jenis data yang diambil dalam penelitian ini adalah data kualitatif dan data kuantitatif. Data kuantitatif untuk menilai kelayakan produk diperoleh dari Alpha Test, Beta Test I dan Beta Test II. Selanjutnya data kuantitatif ini dikonversi ke dalam data kualitatif sehingga bisa diketahui tingkat kualitas dan kelayakan produk yang dikembangkan. Data kuantitatif hasil belajar diperoleh dari nilai test hasil belajar siswa pada pretest dan posttest.

\section{Instrumen Pengumpulan Data}

Instrumen adalah alat yang yang digunakan untuk menggali data yang menghasilkan produk pengembangan multimedia yang berkualitas. Tujuan penyusunan instrumen adalah untuk mengumpulkan data dalam bentuk angket dengan maksud untuk mengetahui kualitas produk multimedia pembelajaran yang dibuat.

Instrumen yang akan digunakan untuk mengumpulkan data pada penelitian ini terdiri dari dua macam instrumen: (1) instrumen untuk mengetahui kelayakan produk yang diisi oleh ahli materi, ahli media, dan siswa pada $\mathrm{Al}$ pha Test dan Beta Test. dan (2) instrumen untuk mengetahui perbedaan hasil belajar siswa sebelum menggunakan multimedia pembelajaran (pretest) dan setelah menggunakan multimedia pembelajaran (posttest) yang akan menunjukkan efektivitas multimedia pembelajaran yang dikembangkan.

\section{Instrumen Penilaian Kelayakan produk}

Instrumen penilaian kelayakan multimedia pembelajaran model simulasi diadaptasi dari indikator-indikator kualitas media dari (Alessi \& Trollip, 2001, p.414-p.431). Berikut kisi-kisi instrumen penilaian kelayakan produk: Pertama angket untuk ahli yang bertujuan untuk memperoleh data tentang kualitas desain pembelajaran. Kedua adalah angket untuk ahli media digunakan untuk memperoleh data tentang kualitas teknis dari produk multimedia pembelajaran yang dihasilkan dan diisi oleh seorang ahli yang kompeten dalam bidang multimedia. Ketiga adalah angket untuk siswa digunakan untuk memperoleh data tentang kualitas produk multimedia pembelajaran dari sudut pandang siswa sebagai subjek uji coba.

\section{Instrumen Test Hasil belajar}

Test hasil belajar dilakukan pada aspek kognitif untuk mengetahui tingkat penguasaan standar kompetensi Memperbarui Halaman Web yang diwujudkan dalam skor test hasil belajar serta untuk mengetahui efektivitas produk pada tahap evaluasi sumatif. Tes hasil belajar dilaksanakan pada kegiatan pretest dan posttest.

Hasil ujicoba instrumen tes dianalisis menggunakan software ITEMAN versi 3.0 yang diproduksi MicroCat System. Analisis item ini digunakan untuk mengetahui tingkat kesukaran, daya beda, dan keefektifan pengecoh.

\section{Validitas dan Reliabilitas}

Instrumen yang baik adalah instrumen yang memenuhi syarat validitas dan reliabilitas serta mampu mendapatkan data yang akurat. Validitas adalah keadaan yang menggambarkan tingkat instrumen yang bersangkutan mampu mengukur apa yang akan diukur (Arikunto, 2010, p.167). Selanjutnya (Sugiyono, 2012, p.173) menyatakan bahwa instrumen yang valid dapat digunakan untuk mengukur apa yang seharusnya hendak diukur.

Syarat instrumen tes disebut valid, jika instrumen tes yang digunakan dalam penelitian ini telah memenuhi validitas konstruksi dan validitas isi. Pengujian validitas konstruksi dilakukan dengan mengkonsultasikan instrumen tes dengan ahli. Setelah pengujian konstruksi oleh para ahli, instrumen tes diujicobakan. Sebuah instrumen tes mempunyai validitas isi apabila instrumen tes tersebut disusun berdasarkan materi pembelajaran yang telah diajarkan sebelumnya. Pengujian validitas isi pada penelitian ini dibantu dengan kisikisi instrumen dan dilakukan dengan meminta pendapat ahli.

Reliabilitas berkenaan dengan tingkat keajegan atau ketetapan hasil pengukuran. Suatu instrumen memiliki tingkat reliabilitas yang memadai, bila instrumen tersebut digunakan untuk mengukur aspek selama beberapa kali mampu menghasilkan hasil yang sama atau relatif sama (Sugiyono, 2011a, p.173).

Instrumen penilaian kelayakan media dikonstruksi dan diadaptasi dari indikator-indi- 
kator kualitas media menurut (Alessi \& Trollip, 2001, p.414-p.431). Selanjutnya, untuk menguji validitas, instrumen tersebut kemudian dikonsultasikan dengan ahli.

\section{Teknik Analisis Data}

Pada penelitian ini, analisis data dilakukan terhadap dua jenis data yaitu data yang diperoleh dari instrumen penilaian kelayakan media dan instrumen tes untuk mengetahui keefektifan multimedia pembelajaran.

Data instrumen penilaian kelayakan media diperoleh dari ahli materi, ahli media, dan siswa. Dalam instrumen penilaian kelayakan produk multimedia, diberikan lima pilihan untuk memberikan tanggapan tentang produk yang dikembangkan, yaitu: sangat baik (5), baik (4), cukup baik (3), kurang baik (2), dan sangat kurang baik (1). Skor yang diperoleh kemudian dikonversikan menjadi data kualitatif skala lima (skala likert). Untuk menentukan kategori dari rerata jawaban siswa dari setiap indikator (item), maka diperlukan konversi skor aktual menjadi nilai dengan acuan tabel yang diadaptasi dari (Sukardjo, 2010, p.100p.101) seperti tersaji pada Tabel 1 berikut.

Tabel 1. Pedoman Konversi Data Kuantitatif ke Data Kualitatif Skala 5

\begin{tabular}{cll}
\hline Nilai & Skor & Kategori \\
\hline 5 & $X>4,21$ & Sangat Baik \\
4 & $3,40<X \leq 4,21$ & Baik \\
3 & $2,60<X \leq 3,40$ & Cukup \\
2 & $1,79<X \leq 2,60$ & Kurang \\
1 & $X \leq 1,79$ & Sangat Kurang \\
\hline
\end{tabular}

Dalam penelitian pengembangan ini, ditetapkan batasan nilai kelayakan minimal produk hasil pengembangan baik dari ahli materi, ahli media, dan penilaian siswa adalah di atas 3,40 atau termasuk kategori Baik. Apabila penilaian dari ahli materi dan ahli media sudah memberikan hasil penilaian akhir secara keseluruhan dengan nilai minimal 3,40, maka produk multimedia pembelajaran tersebut sudah dianggap layak untuk digunakan sebagai sumber belajar.

Selanjutnya evaluasi sumatif dilakukan untuk mengetahui efektivitas produk berupa tingkat penguasaan materi standar kompetensi Memperbarui Halaman Web yang diwujudkan dalam skor tes hasil belajar setelah menggunakan produk hasil pengembangan. Data hasil belajar siswa dianalisis dengan membandingkan skor pretest dengan skor posttest. Peningkatan yang terjadi sebelum menggunakan produk multimedia pembelajaran dan sesudah menggunakan produk multimedia pembelajaran diperhitungkan menggunakan rumus $(\mathrm{N}$ gain) yang ditentukan berdasarkan rata-rata skor gain yang dinormalisasi (g). $\mathrm{S}_{\text {pre }}$ adalah skor tes awal (pretest) sedangkan $\mathrm{S}_{\text {post }}$ adalah skor tes akhir (postest). $\mathrm{S}_{\text {maks }}$ adalah skor maksimum (ideal) dari tes awal (pretest) dan tes akhir (postest). Gain yang dinormalisasi (N-Gain) (Hake, 1998, p.2) dinyatakan dengan persamaan berikut:

$$
\mathrm{g}=\frac{\mathrm{S}_{\text {Post }}-\mathrm{S}_{\text {Pre }}}{\mathrm{S}_{\text {Maks }}-\mathrm{S}_{\text {Pre }}}
$$

Keterangan:

$$
\begin{array}{ll}
\mathrm{g} & \text { : Skor gain yang dinormalisasi } \\
\mathrm{S}_{\text {Post }} & \text { : Skor posttest } \\
\mathrm{S}_{\text {Pre }} & \text { : Skor pretest } \\
\mathrm{S}_{\text {Maks }} & \text { : Skor maksimal }
\end{array}
$$

Tinggi rendahnya gain yang dinormalisasi ( $N$-gain) selanjutnya diinterpretasikan ke dalam Tabel 2 klasifikasi Nilai Gain (Hake, 1998, p.3) berikut:

Tabel 2. Interpretasi Nilai Gain

\begin{tabular}{ll}
\hline Nilai $($ g) & Klasifikasi \\
\hline (N-gain) $\geq 0,7$ & Tinggi \\
$0,7>(\mathrm{N}$-gain $) \geq 0,3$ & Sedang \\
$(\mathrm{N}$-gain $)<0,3$ & Rendah \\
\hline
\end{tabular}

\section{HASIL PENELITIAN}

\section{Deskripsi Data}

Tahap Perencanaan terdiri dari: analisis kebutuhan, pendefinisian bidang/ruang lingkup, mengidentifikasi karakter siswa, menetapkan batasan-batasan produk, membuat projek standar manual, mengumpulkan sumber daya, dan menggambarkan tampilan. 
Tahap Desain terdiri dari: mengembangkan ide awal, analisis tugas dan konsep, deskripsi program, membuat flowchart dan storyboard, dan mempersiapkan naskah.

Tahap terakhir pengembangan terdiri dari: menentukan software pengembang, membuat teks, gambar, audio, video, dan kode, dan menggabungkan bagian-bagian menjadi produk awal.

\section{Hasil Uji Coba Produk}

\section{Data evaluasi kelayakan produk (Alpha Test)}

Penilaian produk oleh tim ahli (Alpha test) terdiri dari validasi ahli materi dan validasi ahli media. Evaluasi kelayakan produk multimedia pembelajaran pada ahli materi terfokus pada komponen lingkup pembelajaran, informasi pelengkap, pertimbangan afektif, dan pedagogi. Sedangkan evaluasi kelayakan produk multimedia pembelajaran oleh ahli media terfokus pada aspek informasi pelengkap, antarmuka, navigasi, pedagogi dan ketahanan produk.

\section{Data Evaluasi Kelayakan Produk oleh Ahli Materi}

Evaluasi kelayakan produk pembelajaran pada ahli materi terfokus pada aspek lingkup pembelajaran, informasi pelengkap, pertimbangan afektif, dan pedagogi. Validasi ahli materi dilakukan oleh Dr. Eko Marpanaji, M.T yaitu Dosen S2 Jurusan Pendidikan Teknologi dan Kejuruan (PTK) pada mata kuliah Pemrograman Web, sekaligus Kepala Puskom Universitas Negeri Yogyakarta yang kompeten di bidang Internet, Komunikasi Data dan Radio Internet.

Proses validasi materi dengan cara memberikan produk dalam bentuk CD dilengkapi dengan instrumen penilaian menggunakan angket skala likert yang terdiri dari 19 butir pertanyaan. Instrumen ini digunakan sebagai acuan untuk memperbaiki materi yang disajikan pada produk yang sedang dikembangkan.

Validasi ahli materi dilaksanakan pada tanggal 28 Mei 2013 bertempat di Puskom Universitas Negeri Yogyakarta. Data yang di- peroleh dari validasi ahli materi dapat dilihat pada tabel 3 .

Tabel 3. Data Penilaian Kualitas Produk oleh Ahli Materi

\begin{tabular}{clcc}
\hline No & \multicolumn{1}{c}{ Indikator } & $\begin{array}{c}\text { Rata2 } \\
\text { skor }\end{array}$ & Kat \\
\hline 1 & Informasi Pelengkap & 4 & $\mathrm{~B}$ \\
2 & Antarmuka & 4,6 & $\mathrm{SB}$ \\
3 & Navigasi & 4 & $\mathrm{~B}$ \\
4 & Pedagogi & 4,6 & $\mathrm{SB}$ \\
5 & Ketahanan Produk & 4 & $\mathrm{~B}$ \\
\hline Rata-rata & Data Keseluruhan & \multicolumn{3}{c}{4.32} \\
\hline Kategori & \multicolumn{3}{c}{ Sangat } \\
\hline
\end{tabular}

Keterangan:

B : Baik, SB : Sangat Baik

\section{Data Evaluasi Kelayakan Produk oleh Ahli Materi}

Penilaian produk pembelajaran pada ahli media terfokus pada komponen Informasi Pelengkap, Hubungan Pengguna dengan Program (antarmuka), Navigasi, Pedagogi, dan Kehandalan Program. Validasi ahli media dilakukan oleh Herman Dwi Surjono, Ph.D yang merupakan Dosen S2 Jurusan Pendidikan Teknologi dan Kejuruan (PTK) dan Teknologi Pendidikan (TP) pada mata kuliah E-Learning, sekaligus Kepala Program Studi Teknologi Pendidikan Program Pascasarjana Universitas Negeri Yogyakarta yang kompeten di bidang E-Learning, Media Pembelajaran, Pembelajaran Teknologi Informasi.

Proses validasi media dengan cara memberikan produk dalam bentuk CD dilengkapi dengan instrumen penilaian menggunakan angket skala likert yang terdiri dari 22 butir pertanyaan. Instrumen ini digunakan sebagai acuan untuk memperbaiki materi yang disajikan pada produk yang sedang dikembangkan.

Validasi ahli media dilaksanakan pada tanggal 28 Mei 2013 bertempat di ruang Kepala Program Studi Teknologi Pembelajaran (TP) Program Pascasarjana Universitas Negeri Yogyakarta. Berikut ini data yang diperoleh dari validasi ahli media: 
Tabel 4. Data Penilaian Kualitas Produk oleh Ahli Media

\begin{tabular}{clcc}
\hline No & \multicolumn{1}{c}{ Indikator } & $\begin{array}{c}\text { Rata2 } \\
\text { skor }\end{array}$ & Kat \\
\hline 1 & Lingkup Pembelajaran & 4,80 & SB \\
2 & Informasi Pelengkap & 5 & SB \\
3 & Pertimbangan Afektif & 4 & B \\
4 & Pedagogi & 4,89 & SB \\
5 & Ketahanan Produk & 4 & B \\
\hline Rata-rata Data Keseluruhan & \multicolumn{2}{c}{4.84} \\
\hline Kategori & \multicolumn{3}{c}{ Sangat Baik } \\
\hline
\end{tabular}

Keterangan:

B : Baik, SB : Sangat Baik

\section{Data Evaluasi Kelayakan Produk Beta Test I}

Evaluasi Kelayakan Produk Beta Test I dilakukan untuk mendapatkan bukti-bukti empiris mengenai kelayakan produk dalam mengidentifikasi kesalahan-kesalahan, serta mendapatkan komentar, saran revisi dan perbaikan terhadap produk yang dikembangkan.

Tabel 5. Data Penilaian Kualitas Produk Beta Test I

\begin{tabular}{clcc}
\hline No & \multicolumn{1}{c}{ Indikator } & $\begin{array}{c}\text { Rata2 } \\
\text { skor }\end{array}$ & Kat \\
\hline 1 & Lingkup Pembelajaran & 4,37 & SB \\
2 & Pertimbangan Afektif & 4,33 & SB \\
3 & Informasi Pelengkap & 4,58 & SB \\
4 & Antarmuka & 4,55 & SB \\
5 & Navigasi & 4,78 & SB \\
6 & Pedagogi & 4,48 & SB \\
7 & Ketahanan Produk & 4,44 & SB \\
\hline Rata-rata Data Keseluruhan & \multicolumn{2}{c}{4.57} \\
\hline Kategori & \multicolumn{3}{c}{ Sangat Baik } \\
\hline
\end{tabular}

Keterangan:

\section{B : Baik, SB : Sangat Baik}

Data Beta Test I diperoleh dari 6 orang siswa yang diambil secara acak dengan kreteria 1 siswa dari kelompok atas, 1 siswa dari kelompok menengah, dan 1 siswa dari kelompok bawah. Pelaksanaan Beta Test I pada tanggal 29 Mei 2013 di laboratorium komputer multimedia I. Subjek uji coba adalah siswa kompetensi keahlian Multimedia.

Data tanggapan siswa terhadap kualitas produk yang dikembangkan terdiri dari 31 butir meliputi komponen lingkup pembelajaran, pertimbangan afektif, informasi pelengkap, hubungan pengguna dengan program (antarmuka), navigasi, pedagogi dan ketahanan produk. Semua data yang diperoleh dari siswa berupa skor dengan rentang 1 sampai 5 .

\section{Data Evaluasi Kelayakan Produk Beta Test II}

Data Beta Test II diperoleh dari 26 orang siswa kompetensi keahlian Multimedia. Pelaksanaan Beta Test II pada tanggal 1 Juni 2013. Beta Test II dilakukan untuk mendapat buktibukti empiris mengenai kelayakan produk, mengidentifikasi kesalahan-kesalahan dan mendapatkan komentar berupa saran/revisi terhadap produk yang sedang dikembangkan. Deskripsi tanggapan siswa dalam Beta Test II terlihat pada Tabel 6 berikut.

Tabel 6. Data Penilaian Kualitas Produk Beta Test II

\begin{tabular}{clcc}
\hline No & \multicolumn{1}{c}{ Indikator } & $\begin{array}{c}\text { Rata2 } \\
\text { skor }\end{array}$ & Kat \\
\hline 1 & Lingkup Pembelajaran & 4,51 & SB \\
2 & Pertimbangan Afektif & 4,73 & SB \\
3 & Informasi Pelengkap & 4,66 & SB \\
4 & Antarmuka & 4,46 & SB \\
5 & Navigasi & 4,68 & SB \\
6 & Pedagogi & 4,64 & SB \\
7 & Ketahanan Produk & 4,47 & SB \\
\hline Rata-rata Data Keseluruhan & \multicolumn{2}{c}{4.51} \\
\hline Kategori & \multicolumn{2}{c}{ Sangat Baik } \\
\hline
\end{tabular}

Keterangan:

\section{B : Baik, SB : Sangat Baik}

Data tanggapan siswa terhadap kualitas produk yang dikembangkan terdiri dari $31 \mathrm{bu}-$ tir meliputi komponen lingkup pembelajaran, pertimbangan afektif, informasi pelengkap, hubungan pengguna dengan program (antarmuka), navigasi, pedagogi dan ketahanan produk. Semua data yang diperoleh dari siswa berupa skor dengan rentang 1 sampai 5 .

\section{Data Hasil Evaluasi Sumatif}

Evaluasi sumatif dilakukan untuk mengetahui efektivitas produk yang dikembangkan dalam proses pembelajaran berupa tingkat penguasaan standar kompetensi Memperbarui Halaman Web yang diwujudkan dalam skor test hasil belajar. Evaluasi sumatif juga dilaku- 
kan untuk mengetahui efektifitas produk saat setelah selesai dikembangkan dan kemudian digunakan dalam proses pembelajaran sesuai materi yang terdapat pada produk yang dikembangkan. Evaluasi sumatif dilakukan pada siswa kelas X kompetensi keahlian Multimedia yang sedang belajar standar kompetensi Memperbarui Halaman Web di semester genap tahun pelajaran 2012/2013.

Pelaksanaan evaluasi sumatif dilakukan pada tanggal 3 Juni 2013 di laboratorium komputer Multimedia SMK Negeri 1 Pengasih. Adapun teknis pelaksanaannya diawali dengan memberikan penjelasan mengenai evaluasi sumatif, siswa diminta mengerjakan pretest, selanjutnya siswa melakukan pembelajaran menggunakan produk multimedia pembelajaran. Setelah melakukan pembelajaran menggunakan multimedia pembelajaran, siswa diberikan posttest untuk mengetahui hasil belajar. Data hasil pretest dan posttest dapat dilihat pada Tabel 7 dan Perbandingan nilai pretest dan posttest pada Tabel 7 berikut ini:

Tabel 7. Perbandingan Nilai Pretest dan Postest

\begin{tabular}{lcccc}
\hline \multirow{2}{*}{ Data } & \multicolumn{2}{c}{ Nilai } & Indexs & Kriteria \\
\cline { 2 - 4 } & Pretest & Postest & Gain & \\
\hline Nilai Min. & 48 & 74 & & \\
Nilai Mak. & 74 & 94 & & \\
Total & 1966 & 2642 & 22,01 & \\
Rata-Rata & 63,42 & 85,23 & 0,71 & Tinggi \\
\hline
\end{tabular}

\section{ANALISIS DATA}

\section{Analisis Data Alpha Test}

\section{Analisis Data Penilaian Ahli Materi}

Berdasarkan hasil penilaian kelayakan produk oleh ahli materi terhadap kualitas produk ditinjau dari komponen lingkup pembelajaran, informasi pelengkap, pertimbangan afektif, dan pedagogi diketahui bahwa rata-rata skor penilaian ahli materi sebesar 4,84. Menurut tabel konversi data kuantitatif ke data kualitatif skala 5, produk ini tergolong pada kategori "Sangat Baik". Berikut secara rinci data 19 butir indikator kualitas produk hasil penilaian ahli materi.
Pada aspek materi terdapat 16 butir $(84,21 \%)$ indikator kualitas pembelajaran dinilai dengan skor 5 (sangat baik), yaitu: (1) Kesesuaian tujuan pembelajaran dengan materi, (2) Struktur isi materi, (3) Keakuratan isi materi, (4) Ketersediaan pengertian kata-kata sulit (Glosari), (5) Ketersediaan petunjuk pengoperasian program (help), (6) Ketersediaan pendahuluan materi, (7) Ketersediaan bantuan, (8) Ketersediaan kesimpulan materi belajar, (9) Metodologi, (10) Interaktivitas, (11) Kapasitas Kognitif, (12) Mendukung terhadap belajar mandiri, (13) Kontrol pengguna, (14) Kualitas umpan balik pada sesi simulasi, (15) Kesesuaian soal dengan materi, (16) Kualitas umpan balik soal pada jawaban benar dan salah.

Sedangkan 3 butir indikator kualitas pembelajaran $(15,79 \%)$ dinilai dengan skor 4 (baik), yaitu (1) Kejelasan penggunaan bahasa, (2) Motivasi, (3) Kemudahan menjawab soal latihan.

Berdasarkan data di atas produk awal (Alpha Test) multimedia pembelajaran Memperbarui Halaman Web menunjukkan bahwa dari komponen Lingkup Pembelajaran, Informasi Pelengkap, Pertimbangan Afektif, dan Pedagogi dianggap sudah layak untuk digunakan sebagai sumber belajar dengan revisi sesuai saran. Hal itu senada seperti yang disampaikan oleh ahli materi yaitu secara keseluruhan Multimedia Pembelajaran sudah sangat baik jika ingin digunakan sebagai sumber belajar.

\section{Analisis Data Penilaian Ahli Media}

Berdasarkan hasil penilaian kualitas produk multimedia pembelajaran oleh ahli media ditinjau dari Komponen Informasi pelengkap, Antarmuka, Navigasi, Pedagogi dan Ketahanan Produk diketahui bahwa rata-rata skor penilaian ahli media sebesar 4,32. Menurut tabel konversi data kuantitatif ke data kualitatif skala 5, produk ini tergolong pada kategori "Sangat Baik". Berikut secara rinci data 22 butir indikator kualitas produk hasil penilaian ahli media.

Pada komponen media terdapat 7 butir (32\%) indikator kualitas pembelajaran dinilai dengan skor 5 (sangat baik), yaitu: (1) Komposisi warna (kesesuaian warna latar belakang 
dengan huruf, gambar, video/simulasi), (2) Kesesuaian penggunaan teks, (3) Kesesuaian penggunaan audio, (4) Kesesuaian penggunaan gambar, (5) Interaktivitas, (6) Mendukung terhadap belajar mandiri, (7) Kualitas umpan balik soal pada jawaban benar dan salah.

Sedangkan 15 (68\%) butir indikator kualitas pembelajaran dinilai dengan skor 4 (baik), yaitu (1) Ketersediaan petunjuk pengoperasian program (help), (2) Ketersediaan pendahuluan materi, (3) Ketersediaan bantuan, (4) Ketersediaan kesimpulan materi belajar, (5) Ketepatan tampilan/layout, (6) Kesesuaian penggunaan video/simulasi, (7) Ketersediaan kontrol player pada penggunaan video/simulasi, (8) Kejelasan tombol navigasi, (9) Konsistensi tombol navigasi, (10) Kemudahan penggunaan tombol navigasi, (11) Kualitas umpan balik pada sesi simulasi, (12) Kemudahan menjawab soal latihan, (13) Untuk penggunaan umum, (14) Untuk penggunaan tidak umum (mengklik bagian-bagian yang tidak seharusnya diklik), (15) Penggunaan pada sistem komputer yang berbeda-beda.

Berdasarkan data di atas menunjukkan bahwa dari komponen Informasi Pelengkap, Antarmuka, Navigasi, Pedagogi, Ketahanan Produk, produk awal multimedia pembelajaran Memperbarui Halaman Web layak untuk digunakan sebagai sumber belajar, hal itu senada seperti yang disampaikan oleh ahli media yaitu secara keseluruhan Multimedia Pembelajaran sudah baik jika ingin digunakan sebagai sumber belajar.

\section{Analisis Data Beta Test I}

Berdasarkan hasil penilaian Beta Test I terhadap kualitas produk ditinjau dari komponen Lingkup Pembelajaran, Pertimbangan Afektif, Informasi Pelengkap, Hubungan Pengguna dengan Program (antarmuka), Navigasi, Pedagogi dan Ketahanan Produk diketahui bahwa rata-rata skor penilaian siswa sebesar 4,51. Menurut tabel konversi data kuantitatif ke data kualitatif skala 5, produk ini tergolong pada kategori "Sangat Baik". Berikut secara rinci data 31 butir indikator kualitas produk hasil penilaian siswa pada Beta Test I.

Hasil penilaian Beta Test I terhadap kualitas produk terdapat 29 butir (94\%) indikator kualitas pembelajaran dinilai dengan skor 5 (sangat baik), yaitu: (1) Kesesuaian materi dengan tujuan pembelajaran, (2) Ketepatan urutan penyajian materi, (3) kejelasan isi materi, (4) Ketersediaan pengertian kata-kata sulit (Glosari), (5) Penggunaan media pembelajaran memberikan motivasi siswa untuk belajar lebih jauh/dalam, (6) Kejelasan petunjuk penggunaan program (help), (7) Ketersediaan pendahuluan materi, (8) Ketersediaan Bantuan pada sesi simulasi, (9) Ketersediaan kesimpulan materi belajar, (10) Komposisi warna (kesesuaian warna latar belakang dengan huruf, gambar, video/simulasi), (11) Ketepatan tampilan/layout, (12) Kesesuaian penggunaan teks, (13) Kesesuaiaan penggunaan audio, (14) Ketersediaan kontrol player pada penggunaan video/simulasi, (15) Keseuaian penggunaan gambar, (16) Kesesuaian penggunaan video/ simulasi, (17) Kejelasan tombol navigasi, (18) Konsistensi tombol navigasi, (19) Kemudahan penggunaan tombol navigasi, (20) Kesesuaian metode pembelajaran yang digunakan (simulasi) dengan materi, (21) Interaktivitas antara pengguna dengan program, (22) Mendukung pengguna untuk belajar mandiri, (23) Ketersediaan kontrol pengguna untuk memilih menu, (24) Ketersediaan umpan balik pada sesi video/ simulasi, (25) Kesesuaian soal dengan materi, (26) Ketersediaan umpan balik pada soal pada jawaban benar dan salah, (27) Untuk penggunaan umum, (28) Untuk penggunaan tidak umum (mengklik bagian-bagian yang tidak seharusnya diklik), (29) Penggunaan pada sistem komputer yang berbeda (Windows, Linux, MacOs).

Sedangkan 2 butir (6\%) indikator kualitas produk dinilai dengan skor 4 (baik), yaitu (1) Kejelasan penggunaan bahasa, dan (2) Kemudahan menjawab soal latihan.

Dari hasil analisis Penilaian Beta Test I di atas, dapat disimpulkan bahwa kualitas multimedia pembelajaran Memperbarui Halaman Web ditinjau dari komponen Lingkup Pembelajaran, Pertimbangan Afektif, Informasi Pelengkap, Hubungan pengguna dengan program (antarmuka), Navigasi, Pedagogi dan Ketahanan Produk adalah Sangat Baik dan layak untuk digunakan sebagai sumber belajar. 


\section{Analisis Data Beta Test II}

Berdasarkan hasil penilaian Beta Test II terhadap kualitas produk ditinjau dari aspek lingkup pembelajaran, pertimbangan afektif, informasi pelengkap, hubungan pengguna dengan program (antarmuka), navigasi, pedagogi dan ketahanan produk diketahui bahwa rata-rata skor penilaian siswa sebesar 4,59. Menurut tabel konversi data kuantitatif ke data kualitatif skala 5, produk ini tergolong pada kategori "Sangat Baik". Berikut secara rinci data 31 butir indikator kualitas produk hasil penilaian siswa.

Hasil penilaian Beta Test II terhadap kualitas produk terdapat 28 butir $(90,32 \%)$ indikator kualitas pembelajaran dinilai dengan skor 5 (sangat baik), yaitu: (1) Kesesuaian materi dengan tujuan pembelajaran, (2) Ketepatan urutan penyajian materi, (3) Kejelasan isi materi, (4) Penggunaan media pembelajaran memberikan motivasi siswa untuk belajar lebih jauh/dalam, (5) Kejelasan petunjuk penggunaan program (help), (6) Ketersediaan pendahuluan materi, (7) Ketersediaan Bantuan pada sesi simulasi, (8) Ketersediaan kesimpulan materi belajar, (9) Komposisi warna (kesesuaian warna latar belakang dengan huruf, gambar, video/simulasi), (10) Ketepatan tampilan/layout, (11) Kesesuaian penggunaan teks, (12) Ketersediaan kontrol player pada penggunaan video/simulasi, (13) Keseuaian penggunaan gambar, (14) Kesesuaian penggunaan video/simulasi, (15) Kejelasan tombol navigasi, (16) Konsistensi tombol navigasi, (17) Kemudahan penggunaan tombol navigasi, (18) Kesesuaian metode pembelajaran yang digunakan (simulasi) dengan materi, (19) Interaktivitas antara pengguna dengan program, (20) Mendukung pengguna untuk belajar mandiri, (21) Ketersediaan kontrol pengguna untuk memilih menu, (22) Ketersediaan umpan balik pada sesi video/simulasi, (23) Kesesuaian soal dengan materi, (24) Kemudahan menjawab soal latihan, (25) Ketersediaan umpan balik pada soal pada jawaban benar dan salah, (26) Untuk penggunaan umum, (27) Untuk penggunaan tidak umum (mengklik bagian-bagian yang tidak seharusnya diklik), (28) Penggunaan pada sistem komputer yang berbeda (Windows, Linux, MacOs).

Sedangkan 3 butir (9,68\%) indikator kual- itas produk dinilai dengan skor 4 (baik), yaitu (1) Kejelasan penggunaan bahasa, dan (2) Ketersediaan pengertian kata-kata sulit (Glosari), (3) Kesesuaiaan penggunaan audio.

Dari hasil analisis Beta Test II di atas, dapat disimpulkan bahwa kualitas multimedia pembelajaran Memperbarui Halaman Web ditinjau dari aspek lingkup pembelajaran, pertimbangan afektif, informasi pelengkap, hubungan pengguna dengan program (antarmuka), navigasi, pedagogi dan ketahanan produk adalah sangat baik dan layak untuk digunakan sebagai sumber belajar.

\section{Analisis Data Test Sumatif}

Evaluasi sumatif dilakukan untuk mengetahui efektivitas produk berupa tingkat penguasaan standar kompetensi Memperbarui Halaman Web yang diwujudkan dalam skor tes hasil belajar setelah menggunakan produk yang dikembangkan. Perbedaan hasil belajar dapat dilihat jelas melalui selisih nilai posttestpretest (N-Gain Skor). Berdasarkan analisis data evaluasi sumatif secara visual tampak pada Gambar 1 berikut:

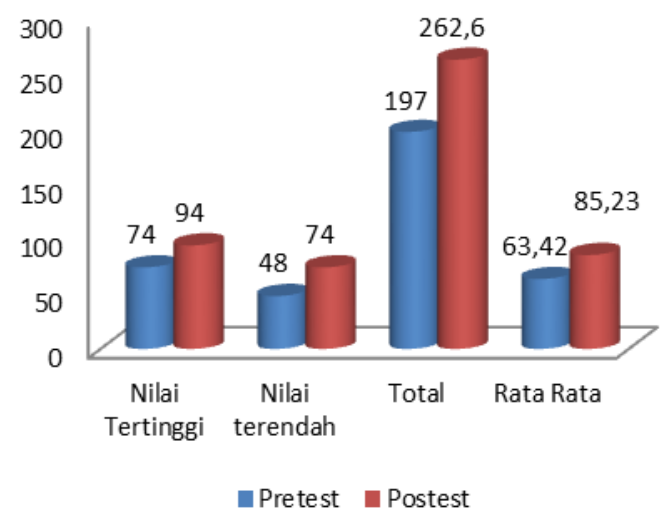

\section{Gambar 1. Diagram Hasil Test Sumatif}

Pada tampilan di atas dapat dijelaskan bahwa nilai terendah pretest sebesar 48 dan nilai tertinggi 74 . Dengan rata-rata nilai sebesar 63,42 . Sedangkan setelah menggunakan produk multimedia pembelajaran dan diberikan posttest nilai terendah sebesar 74 dan nilai tertinggi sebesar 94 dengan jumlah rata-rata 85,23 . Peningkatan N-gain skor nilai antara pretest dan posttest sebesar 0,71 dengan klasifikasi tinggi. 
Berdasarkan interpretasi N-gain, maka dapat disimpulkan bahwa hasil belajar posttest lebih baik dari pada hasil pretest dengan perbedaan selisih hasil belajar siswa meningkat sebesar 0,71 dengan klasifikasi N-Gain tinggi. Peningkatan N-Gain dengan klasifikasi tinggi setelah menggunakan multimedia pembelajaran menunjukkan bahwa efektivitas pembelajaran meningkat berupa penguasan kompetensi belajar yang diwujudkan dalam bentuk skor tes hasil belajar siswa.

\section{Revisi Produk}

\section{Revisi Produk Ahli Materi}

Berdasarkan analisis data validasi oleh ahli materi, pengembang melakukan beberapa revisi berdasarkan saran perbaikan. Revisi yang dilakukan berdasarkan saran dari ahli materi adalah memperbaiki warna text box, jenis teks, ukuran teks dan posisi text box pada bagian umpan balik Materi KD 1 dengan warna teks box yang jelas dan menarik, penempatan text box yang tepat, warna teks dan jenis teks terbaca dengan jelas.

\section{Revisi Produk Ahli Media}

Berdasarkan analisis data validasi oleh ahli media, pengembang melakukan beberapa revisi berdasarkan saran perbaikan. Revisi yang dilakukan berdasarkan saran dari ahli materi yang pertama adalah menambahkan mengenai informasi pengembang (nama, NIM, jurusan) dan target media dibuat (jenjang sekolah, kelas, kompetensi keahlian, semester). Revisi selanjutnya pada button ditambahkan gambar atau tanda tertentu untuk membedakan pada materi/halaman yang sedang aktif dengan yang tidak. Berdasarkan saran dari ahli media maka dilakukan revisi sesuai saran. Perubahan dilakukan untuk semua menu yang memiliki sub menu, yaitu pendahuluan, materi, glosarium, soal, profil dan petunjuk menggunakan program

\section{Revisi Produk Beta Test I}

Hasil penilaian kualitas produk dari Beta Test I tidak ada revisi, tetapi siswa memberikan saran dan masukan untuk pengembangan produk multimedia selanjutnya sebagai berikut: multimedia yang dikembangkan sebaiknya diperbanyak soal latihan dan model soalnya dapat lebih bervariasi, tidak hanya mengerjakan soal dalam bentuk test pilihan ganda melainkan dalam bentuk essai, menjodohkan dan lain-lain. Berdasarkan saran dan masukkan tersebut, peneliti akan masukkan dalam kelemahan multimedia yang dikembangkan. Sehingga jika pengembang berniat mengembangkan kembali multimedia pembelajaran ini akan mempertimbangkan saran dan masukan siswa.

\section{Revisi Produk Beta Test II}

Hasil penilaian kualitas produk dari Beta Test II tidak ada revisi. Pada bagian ini siswa memberikan saran dan masukan antara lain, kualitas audio ditingkatkan dan jeda pada sesi simulasi tidak terlalu lama.

\section{Kajian Produk Akhir}

Pengembangan produk multimedia pembelajaran pada standar kompetensi Memperbarui Halaman Web ini telah selesai dikembangkan melalui 3 (tiga) tahapan utama yang meliputi tahap perencanaan, tahap desain, dan tahap pengembangan produk. Proses pengembangan produk dilakukan dengan menggunakan software utama yaitu Adobe Captivate 4 dan software pendukung yaitu Adobe Flash CS3, Adobe Firework CS3, dan Adobe Audition 1.5.

Uji coba produk yang dilakukan untuk mengetahui kelayakan produk multimedia meliputi beberapa tahapan evaluasi diantaranya adalah (1) evaluasi formatif yaitu Aplha Test yang merupakan validasi oleh ahli materi dan validasi oleh ahli media, Beta Test I merupakan uji coba produk dengan 6 subyek, serta Beta Test II merupakan uji coba produk dengan 26 subyek; (2) evaluasi sumatif dilakukan untuk mengetahui efektivitas produk terhadap peningkatan skor test hasil belajar dengan subyek sebanyak 31 siswa kelas X kompetensi keahlian Multimedia menggunakan produk akhir multimedia pembelajaran.

Hasil penilaian kualitas produk oleh ahli materi ditinjau dari lingkup pembelajaran diperoleh skor sebesar 4,80 (kategori sangat baik), informasi pelengkap skor sebesar 4,88 (kategori sangat baik), pertimbangan afektif skor sebesar 4 (kategori baik), dan pedagogi skor sebesar 4,89 (kategori sangat baik). Ratarata keseluruhan adalah 4,89 dengan kategori "Sangat Baik". 
Hasil penilaian kualitas produk oleh ahli media ditinjau dari informasi pelengkap diperoleh skor sebesar 4,00 (kategori baik), hubungan pengguna dengan program (antarmuka) skor sebesar 4,60 (kategori sangat baik), aspek navigasi skor sebesar 4 (kategori baik) aspek produk dengan skor sebesar 4 (kategori baik). Rata-rata keseluruhan adalah 4,32 dengan kategori "Sangat Baik".

Hasil penilaian Beta Test I terhadap kualitas produk ditinjau dari lingkup pembelajaran diperoleh rerata skor sebesar 4,37 (kategori sangat baik), pertimbangan afektif rerata skor sebesar 4,33 (kategori sangat baik), informasi pelengkap rerata skor sebesar 4,58 (kategori sangat baik), hubungan pengguna dengan program (antarmuka) rerata skor sebesar 4,55 (kategori sangat baik), navigasi rerata skor sebesar 4,78 (kategori sangat baik), pedagogi rerata skor sebesar 4,48 (kategori sangat baik), ketahanan produk dengan rerata skor sebesar 4,44 (kategori sangat baik). Rata-rata keseluruhan adalah 4,51 dengan kategori "Sangat Baik".

Hasil penilaian Beta Test II terhadap kualitas produk ditinjau dari lingkup pembelajaran diperoleh rerata skor sebesar 4,51 (kategori sangat baik), pertimbangan afektif rerata skor sebesar 4,73 (kategori sangat baik), informasi pelengkap rerata skor sebesar 4,66 (kategori sangat baik), hubungan pengguna dengan program (antarmuka) rerata skor sebesar 4,46 (kategori sangat baik), navigasi rerata skor sebesar 4,68 (kategori sangat baik), pedagogi rerata skor sebesar 4,64 (kategori sangat baik), ketahanan produk dengan rerata skor sebesar 4,47 (kategori sangat baik). Rata-rata keseluruhan adalah 4,57 dengan kategori "Sangat Baik".

Berdasarkan dari keempat aspek penilaian di atas maka dapat disimpulkan bahwa produk multimedia pembelajaran yang dikembangkan termasuk kategori "Sangat Baik" sehingga produk multimedia pembelajaran ini layak digunakan sebagai sumber belajar mandiri siswa.

Pada tahap evaluasi sumatif dilakukan uji efektivitas berupa peningkatan skor test hasil belajar siswa pada standar kompetensi Memperbarui Halaman Web setelah menggunakan produk multimedia pembelajaran. Hasil evaluasi sumatif diketahui skor test hasil belajar meningkat dengan $\mathrm{N}$-gain skor sebesar 0,71 dengan klasifikasi "tinggi". Berdasarkan hasil tersebut dapat disimpulkan nilai hasil belajar siswa meningkat setelah menggunakan dan memanfaatkan produk multimedia pembelajaran.

Selama proses penelitian, siswa memberikan tanggapan mengenai produk multimedia pembelajaran yang dikembangkan. Beberapa hal yang menjadi kelebihan produk multimedia pembelajaran ini antara lain: (1) produk multimedia pembelajaran menggunakan model simulasi ini bermanfaat bagi siswa SMK kompetensi keahlian Multimedia sebab bisa membantu meningkatkan pemahaman standar kompetensi memperbarui halaman web, (2) materi yang disampaikan menarik ditambah dengan penyampaian yang bagus dan mempermudah pemahaman siswa, (3) simulasi yang diberikan bagus, dan menurut siswa lebih mudah dipahami daripada pembelajaran metode ceramah dan demonstrasi menggunakan sumber belajar modul dan buku teks, (4) produk pembelajaran model simulasi ini, memberikan siswa kemudahan dalam memahami materi yang diberikan, karena siswa dapat memutar ulang media pembelajaran ini, (5) tampilannya sudah bagus (desainnya cocok untuk anak SMK), menarik, tidak membosankan dan membuat tidak malas belajar, (6) interaktif karena siswa bebas memilih materi yang ingin dipelajari.

Melalui tanggapan siswa tersebut maka dapat diketahui bahwa ketertarikan siswa terhadap multimedia dapat meningkatkan motivasi siswa untuk belajar sehingga meningkatkan skor test hasil belajar siswa. Selain kelebihan tersebut di atas terdapat beberapa kekurangan antara lain: (1) pelaksanaan pembelajaran menggunakan produk multimedia harus menyediakan headset untuk masing-masing komputer agar pada saat menggunakan multimedia pembelajaran mengganggu yang lainnya, (2) soal latihan masih dianggap kurang banyak sehingga perlu diperbanyak jumlah dan variasinya, (3) kualitas audio masih perlu ditingkatkan dan jeda pada sesi simulasi dapat diperpendek atau tidak terlalu lama.

\section{Keterbatasan Penelitian}

Penelitian dan pengembangan produk multimedia pembelajaran standar kompetensi Memperbarui Halaman Web ini memiliki ket- 
erbatasan, antara lain: (1) produk yang dihasilkan belum sempurna dan masih harus terus dikembangkan, misalnya dalam hal kualitas audio pada sesi simulasi, dan jeda pada sesi simulasi masih panjang, dan (2) Pengujian ini hanya dilakukan dengan cara membandingkan hasil belajar siswa pada saat pretest dan postest saja, tidak sampai membandingkan antara penggunaan produk multimedia pembelajaran dengan yang menggunakan media lainnya.

\section{KESIMPULAN DAN SARAN}

\section{Kesimpulan Tentang Produk}

Berdasarkan hasil penelitian dan pengembangan multimedia pembelajaran pada standar kompetensi memperbarui halaman web, dapat disimpulkan sebagai berikut: (1) prosedur pengembangan produk multimedia pembelajaran ini melalui tiga tahapan yaitu Tahap Perencanaan; Tahap Desain; dan Tahap Pengembangan. Produk yang dihasilkan berupa multimedia pembelajaran pada standar kompetensi memperbarui halaman web untuk siswa kelas X Kompetensi Keahlian Multimedia dalam bentuk CD (Compact Disk) dan file html/exe yang disimpan di web server dan flash disk, (2) multimedia pembelajaran yang dikembangkan dinilai layak digunakan sebagai sumber belajar berdasarkan uji kelayakan produk oleh Ahli Materi dengan skor 4.84 (kategori sangat baik), (3) multimedia pembelajaran yang dikembangkan dinilai layak digunakan sebagai sumber belajar berdasarkan uji kelayakan produk oleh Ahli Media dengan skor 4.32 (kategori sangat baik), (4) multimedia pembelajaran yang dikembangkan dinilai layak digunakan sebagai sumber belajar berdasarkan uji kelayakan produk oleh siswa pada Beta Test I dengan skor 4.51 (kategori sangat baik), Beta Test II dengan skor 4.57 (kategori sangat baik), dan (5) produk multimedia pembelajaran pada standar kompetensi memperbarui halaman web dapat meningkatkan hasil belajar yang dibuktikan dengan skor test hasil belajar pada evaluasi sumatif yang digunakan untuk menguji efektivitas produk berdasarkan selisih perbedaan hasil (N-Gain) skor yang diperoleh siswa pada saat pretest dan posttest. Rata-rata hasil belajar siswa pada saat pretest diperoleh skor sebesar
63,42; sedangkan rata-rata hasil belajar siswa pada posttest dan telah menggunakan multimedia pembelajaran sebagai sumber belajar mandiri diperoleh skor sebesar 85,23. Peningkatan rata-rata $\mathrm{N}$-Gain skor nilai antara pretest dan posttest sebesar 0.71 dan tergolong pada klasifikasi N-Gain tinggi. Berdasarkan hasil N-Gain Skor yang tergolong tinggi maka dapat disimpulkan bahwa multimedia pembelajaran yang dikembangkan efektif dan dapat meningkatkan hasil belajar pada standar kompetensi memperbarui halaman web.

\section{Saran Pemanfaatan dan Diseminasi.}

\section{Saran Pemanfaatan}

Sebelum siswa menggunakan multimedia pembelajaran sebaiknya diberikan penjelasan terlebih dahulu tentang cara penggunaannya atau mempelajari petunjuk penggunaan yang telah tersedia di menu help. Bagi sekolah yang laboratorium komputernya belum dilengkapi speaker sebaiknya masing-masing komputer dapat menggunakan headset agar siswa dapat belajar dan mendengarkan video/simulasi tanpa mengganggu siswa yang lainnya. Sekolah yang telah memiliki jaringan komputer, sebaiknya multimedia pembelajaran ini disimpan di web server dengan ektensi file *.html sehingga dapat menghemat biaya untuk penggandaan CD (Compact Disk). Pemanfaatan multimedia pembelajaran ini tidak hanya terbatas pada kegiatan pembelajaran di laboratorium komputer saja, melainkan dapat dijadikan sebagai sumber belajar mandiri dengan menyimpannya di flash disk untuk dapat dibuka dan dipelajari di rumah, warnet ataupun rental komputer.

\section{Diseminasi}

Produk multimedia pembelajaran ini dapat dimanfaatkan lebih luas dengan terus dikembangkan dan disosialisasikan kepada guru-guru melalui forum MGMP Multimedia.

\section{Pengembangan Produk Lebih Lanjut}

Pengembangan produk lebih lanjut perlu memperhatikan beberapa hal yaitu: (1) teknik evaluasi yang mampu mengukur aspek psikomotorik siswa setelah menggunakan produk multimedia pembelajaran ini, (2) produk multimedia pembelajaran sebaiknya dileng- 
kapi dengan mode Assessment Simulation, (3) produk multimedia pembelajaran perlu diperbanyak latihan soal dan evaluasi yang lebih bervariasi. Produk multimedia pembelajaran ini baru menyediakan bentuk soal-soal pilihan ganda sehingga perlu disajikan bentuk soal lainnya seperti butir soal benar-salah, butir soal menjodohkan dan butir soal essai, (4) perlu diupayakan kegiatan penelitian lebih lanjut untuk mengetahui tingkat efektivitas penggunaan produk multimedia pembelajaran ini baik dengan metode penelitian tindakan kelas maupun penelitian eksperimen dengan kelompok sasaran yang lebih luas.

\section{DAFTAR PUSTAKA}

Alessi, S.M., \& Trollip, S.R. (2001). Multimedia for learning: methods and development ( $3^{\text {rd }}$ Edition). Boston: Allyn and Bacon.
Arikunto, S. (2010). Manajemen penelitian. Jakarta: Rineka Cipta.

Hake, R.R. (1998). Interactive engagement methods in introductory mechanicscourses. Departement of Physics, Indiana University, Bloomingtoon. diambil pada tanggal 2 Mei 2013, dari http:// www.iub.edu/ iubphys/

Munir. (2012). Multimedia konsep \& aplikasi dalam pendidikan. Bandung: Alfabeta.

Sugiyono. (2011a). Metode penelitian pendidikan. Bandung: Penerbit Alfabeta.

Sugiyono. (2012). Statistika Untuk Penelitian. Bandung: Penerbit Alfabeta.

Sukardjo. (2005). Modul perkuliahan evaluasi pembelajaran. Yogyakarta: Program Pascasarjana Universitas Yogyakarta.

Sutopo, A.H. 2003. Multimedia interaktif dengan flash. Yogyakarta: Graha Ilmu. 